\title{
Effects of Concept Mapping Instructional Strategy on Students' Academic Performance and Interest in Technical Drawing in Technical Colleges in Edo State, Nigeria
}

\author{
Dr. (Mrs.) Jane Itohan Oviawe ${ }^{1}$, Dr. Adeola Lukmon ${ }^{2}$ \\ ${ }^{1}$ Department of Vocational and Technical Education Ambrose Alli University, Ekpoma, Edo State, Nigeria \\ ${ }^{2}$ Provost, Tai Solarin College of Education, Omu Ijebu, Ogun State, Nigeria
}

\begin{abstract}
This study was designed to determine the effect of concept mapping strategy on students' academic performance and interest in technical drawing in technical colleges in Edo State, Nigeria. A pretest, posttest, non equivalent control group, quasi-experimental research design was adopted. Two research questions and two hypotheses tested at 0.05 level of significance guided the study. 61 students made up the experimental group and 56 students in the control group for the study; giving a total of 117 year II technical students in 2015/2016 academic session drawn from the four Edo State owned technical colleges made up the sample for this study. Two instruments: Technical Drawing Achievement Test (TDAT) and Technical Drawing Interest Inventory (TDII) were used for data collection. Concept mapping approach and conventional lesson plans were prepared by the researcher. The instruments were face and content validated by five experts in Technical Education and Test and measurement. The reliability coefficient of TDAT was found to be 0.78 using Kuder-Richardson's estimate while that of TDII was 0.85 using Cronbach Alpha statistics. Research questions were answered using Mean while the hypotheses were tested using ANCOVA. The findings revealed among others that students taught technical drawing using concept mapping teaching strategy had higher mean achievement and interest scores than those taught with the conventional teaching method. It was recommended among others that technical teachers should use concept mapping in teaching technical drawing.
\end{abstract}

Keywords: concept mapping, interest, technical drawing

\section{Introduction}

Technical drawing is the language of technology. It is the most popular technical subject in any technical education programme be it at the Universities, Polytechnics, Colleges of Education (Technical), technical colleges or secondary schools. Technical Drawing is a skill oriented subject or course that encompasses work done by architects, engineers, interior designers and electricians, technical drafters, craftsmen and technical teacher educators and students. Technical drawing is essentially the universal and graphic language used by architects, technicians, engineers, technologists, designers, craftsmen, operators, manufacturers and industrialists to communicate ideas by means of pictures, drawings, graphics and symbols (Okorie 2001). Okoro (1993) asserted that the usability of technical drawing transcends cultures and languages and for any nation to progress technologically, such nation must develop the training of her citizens in the language of technology which is technical drawing.

Ekwu (2003) in Oviawe (2016) described Technical drawing as the prime mover of all other technical related subject that forms a picture of concept of what should be drawn before actually drawing it. He added that greater form is done where the teacher finds it difficult to assist students create the image of the picture required. These difficulties, according to Okoro (1993) are of a mechanic tradition. He added that Nigeria as a developing nation is just starting to experience the technology age, with the result that most of her young people, unlike youths elsewhere have had no acquaintance with machines, mechanical knowledge, attitude, habits and thinking that are normal part of growing up in a technology culture. This clearly implies that something is lacking in Nigeria's quest for technological growth and development. To this end, Collins (2000) in Oviawe (2016) posited that the required background that ought to be the foundation for the study of engineering and technology which is technical drawing is missing. Collins further asserted that this forms the basis for the technological culture most researchers refer to. Technical drawing needs a high level of imagination and vision; and students are required to acquire or possess the creative skills to enable them perform well in technical drawing.

Despite the importance of technical drawing to technology education, researches reveal that technical drawing achievement of students has been on a steady decline over the years. This could be seen from Chief Examiners' report of the National Business and Technical Examination Board (NABTEB) whose comments from 2009 to $2013 \mathrm{kept}$ reporting a poor performance of students in technical subjects. Similarly, the National Board for Technical Education in the year 2009, 2010, 2011 and 2012 asserted that the overall achievement of students in technical drawing has been quite low with the highest mean score in technical drawing recorded as 
$34.67 \%, 38 \%, 40.43 \%$ and $27.78 \%$ respectively (NBTE, 2012). The reasons for this low achievement include: the negative attitude of Nigerians towards technical and vocational subjects (Aduda, 2003). The foregoing reports suggest that the mastery of technical drawing in Nigeria is at a shallow level and needs to be improved on. The students' underachievement in technical drawing has been a major concern to parents, technical teachers and technical teacher educators and curriculum experts across the nation and they are eager to embrace any effort geared towards ameliorating this ugly menace.

Many reasons account for students' poor performance in science and technology areas as reported by researchers. Oviawe, Ezeji \& Uwameiye (2015) identified poor teaching approach and instructional strategy; lack of confidence in the subject (Abkpa \& Iji (2011); poor learning environment (Olunloye, 2010) as reasons for students under achievement. Similarly, the unique and standardized teaching material provided to all learners tends to be of unique benefit to only those students whose learning style and background knowledge fit well with the teaching materials. This does not take care of the individual differences that exist between the learners such as learning styles, abilities, background knowledge (Ford \& Chen, 2001). Aduda (2003) noted that Nigerians have negative attitude towards technical/vocational subjects as compared to arts subjects. However, literature is abounding with evidence to show that some learners' personality variables such as interest (Keter, Barchok \& Ng'ene, 2014) could influence students learning outcomes irrespective of the instructional strategy used.

Interest is the attraction which forces or compels a child to respond to a particular stimulus. It is an aspect of affective domain that deals with ones readiness to like or dislike something. Something could be aroused in a person by activity that tends to satisfy the person's need. Interest is a subjective feeling of concentration or persisting tendency to pay attention and enjoy some activity or content (Imoko \& Agwagah, 2006). Though some students may be intellectually and physically capable of learning, they may never learn until their interest is stimulated. Once the students are stimulated, they will come to learn as long as the teacher is capable of sustaining their interest in the subject matter. This is because interest is a sign of attention, once there is direct interest, attention is guaranteed and learning is assured.

Researchers (Obioma, 2005; Okereke, 2006; Imoko \& Agwagah, 2006; Iyekekpolor, 2007; Anyagh \& Ok'wu, 2010) have identified curriculum, examination bodies, teachers, students, environment, textbooks, lack of interest on the part of the students, incompetent teachers, perception that a subject is difficult, large class syndrome, psychological fear of the subject, poor methods of teaching and lack of qualified teachers as factors responsible for students' low interest and poor performance. This implies that their interest towards technical drawing is low, this could be attributed to conventional teaching method used in teaching technical drawing. This situation calls for drastic and deliberate intervention in order to motivate students towards the learning of technical drawing. This can only be made possible through the use of appropriate teaching approach that can be achieved through professional development of technology teachers (Keter, Barchok \& Ng'ene, 2014). Aina (2000) in Federal Ministry of Education (2001) asserted that the teaching approach that a teacher uses is a major factor that may influence or mar the interest of the students.

Since in learning any of the skills of technology, technical drawing is involved, improving students' achievement in the subject is therefore necessary. This calls for search for strategy that might help in learning, understanding and using it. Use of concept mapping strategy in teaching technical drawing could help out as it actively engages students in worthwhile classroom activities as perceived (Eneasato, 2010).

A map must challenge an individual's assumption; recognize new connections and visualize the unknown (Wandersee, 1999 in Imoko \& Agwagah, 2006). Concept mapping is used to deliver instruction for brain strumming, note-taking, memory retention, summary, new knowledge creation and to increase meaningful learning (Brown, 2002 in Imoko, 2005). According to Cakir (2008), concept mapping is a schematic representation of ideas or concepts, showing their relationship in form of flow chart. It is a visual representation which allows the development of a wholistic understanding that words alone cannot convey (Plotnick, 2002 in Imoko \& Agwagah, 2006). It is a diagram with hierarchical nodes, labeled with concepts. It is divided into two nodes (circle) and links (lines). Nodes often represent various concepts while links represent the relationship (Propositions) between concepts (Walker, 2002). The nodes are linked together with directional lines and are arranged from general specific; with words used to label the links in order to depict relationship explicitly.

Concept mapping is a visual organizer that helps students represents a topic or concept by showing its relationships (Novak, 2008). Concept mapping, though similar to flow chart or outline, in organizing knowledge differs from them as it shows relationship between concepts even including bidirectional relationship (Walker, 2002). Concept map, according to Coffey \& Canas (2003) differs from outlining in that it is more explicit for the learning of relationship among concepts since outline shows mainly hierarchies, not interrelationships.

To this end, Elorriaga (2006) posited that in recent times it has become evident to researchers that representing knowledge in a visual format allows one to better recognize and understand incoming information. It might be easier for the brain to interpret data when information is presented in visual formats for visual symbols are quickly and easily recognized. Concept mapping strategy helps in representing knowledge in this 
visual format. This can improve the performance of students in technical drawing. Hence, technical drawing could be effectively learnt when the students are made to construct their own understanding of a leant concept in technical drawing.

Concept maps are typically hierarchical, with the subordinate concepts stemming from the main concept or idea. This type of graphic organizer always allows change and new concepts to be added. In constructing a concept map, it is essential to begin with a domain of knowledge that is very familiar to the individual constructing the map. Such domain should be the main idea where the additional ideas can stem out. Concept map structures are always dependent on the context in which they will be used. This creates a context that will help to determine the hierarchical structure of the concept map and to select a limited domain of knowledge for the construction of the first concept maps of the domain (Novak, 2008). When a domain is selected, the key concepts related to the domain should be identified and from them the concept map is developed. The steps in constructing concept map according to Walker (2002) are: (i) write down major terms or concepts about the topic; (ii) identify the most general, intermediate, and specific concepts; (iii) begin drawing the concept map: concepts are circled; place the most general concepts at the top; place intermediate concepts below general concepts; (iv) draw lines between related concepts; (v) label the lines with 'linking words' to indicate how the concepts are related; and (vi) revise the map.

The construction of a learnt concept by the learners assists in internalizing what was learnt and so improve their performance in the task. Lippincott (1970) in Imoko \& Agwagah (2006) reported that students do not do well because of the teachers' authoritarian and introverted style. If technical drawing is too difficult to the students and the teacher's instructional method can go a long way to improve students' performance, hence the problem of this study was to find out the effect of concept maps on students' performance and interest in technical drawing.

\section{Purpose of the Study}

The purpose of the study is to determine the effect of concept mapping on students' performance in Technical Drawing. Specifically, this study sought to find out the:

1. effect of concept mapping on students' performance in Technical Drawing.

2. effect of concept mapping on students interest in Technical Drawing

\section{Method of Study}

The design of the study is a quasi-experimental research design. Specifically, non-equivalent pretest, posttest control group design since intact classes were used. Quasi-experimental research design is a design that uses non-randomized group and this option occurs when the researcher cannot sample and assign subjects to treatment groups (Ali, 2006). The use of intact classes to determine the effect of concept mapping strategy on students' performance and interest in technical drawing in Edo State technical colleges was to avoid threat of selection bias among the students and to avoid re-arranging and re-grouping which could disrupt the normal lessons. The pretest was used to partial out initial differences in the two groups and also to control selection bias which is a threat to internal validity. The target population for this study consisted of 117 Year II technical students offering technical drawing in the four technical colleges in Edo State. Purposive sampling technique was used since there are four technical colleges owned by Edo State Government and the population size is manageable. The four colleges were grouped into two. Two technical colleges were used as experimental group and the other two as control group. Intact classes were used in each school for experimental and control.

The instruments used for data collection were the researcher developed Technical Drawing Achievement test (TDAT) and Technical Drawing Interest Inventory (TDII). TDAT as developed by the researcher is a paper and pencil 50-item multiple choice objective test with four-options (A to D) multiple choice objective test based on the NBTE (2003) curriculum. The test was used for both Pre-test (PRETDAT) and Post-test (POSTTDAT). There was a six weeks interval between pretest and posttest. This was to create enough time to take care of the possibility of the students becoming "test wise". The Pre-test (PRETDAT) was used to establish the level of achievement at which the students functioned in Technical Drawing prior to treatment. At the end of the treatment, the Post-test (POSTTDAT) was conducted. It was used to establish the level of performance at which the students attained in Technical Drawing after treatment. The items in TDAT used for pretest were reshuffled for use as posttest. Also, concept maps and lesson plans for both the experimental and control groups were developed by the researcher. The Institute for Human Cognition Concept Map (IHCCM) tools (Novak, 2008) provides bases that were used in constructing the concept map. Since it is important to begin from the domain which is very familiar with the person to use the map, the following steps were involved in the construction: (i) the topics; (ii) identification of key concepts (general, intermediate and specific); and (iii) construction of maps. To adapt the TDII for students, some words on the instrument were adjusted and replaced with technical drawing. Items of TDII were based on four point scale and was rated and scored as: Like Very Much (LVM =4), Like Much (LM=3), Like Little (LL=2), and Do Not Like (DNL=1). 
TDAT, TDII and lesson plans were face and content validated by a technical drawing lecturer, an expert from educational psychology, an expert in test and measurement from Ambrose Alli University, Ekpoma and two technical drawing teachers from technical colleges. Based on their criticism and corrections, a final draft of the instruments which were used for data collection resulted.

TDAT and TDII were administered on an equivalent technical college not included in the main study sample to determine the coefficient of stability of the instruments. This was done to prevent contamination of study samples and results obtained in the course of the study. The results obtained were used to calculate the difficulty index and discrimination index of the items. The reliability of the test items was determined using Kuder Richardson formula (K-R 20) and the reliability of 0.78 was obtained. Cronbach Alpha was used to establish the reliability of TDII and it yielded a coefficient of 0.85 .

Data collected were analyzed using mean to answer the research questions while Analysis of Covariance (ANCOVA) was used in testing the hypotheses at 0.05 level of significance.

The regular teachers were coached on the lesson plan prepared for the experimental classes which was used for the students by their teachers while the teachers in the control group were allowed to teach normally using the conventional teaching method. The regular teachers were allowed to teach both groups to take care of hawthorn effect which might result when the students are aware that they are engaged in an experiment while the researchers only supervised the teaching and testing processes. To ascertain the pre-existing differences in technical drawing achievement and interest between groups, the TDAT and TDII were administered as a pretest to the students and the results were used as covariate measures to the posttest scores. Both the test and the teachings for the subjects in the experimental and control groups were held during normal school timetable schedule. Then the researchers with the assistance of the teachers finally administered the posttest (TDAT and TDII) to the students under a uniform testing atmosphere. The results of both the pretest and posttest were collated and were used to answer the two research questions and to test the null hypotheses.

\section{Findings}

Research Question 1: What is the effect of concept mapping on students' achievement in Technical Drawing?

Table 1: Mean and Standard Deviation of Pretest Post-test mean Performance of Students' taught Technical Drawing using Concept Mapping and Conventional Teaching Method

\begin{tabular}{|lccccccc|}
\hline Group & \multicolumn{2}{c}{ Pre-test } & \multicolumn{2}{c|}{ Post-test } & \multicolumn{2}{c|}{ Gains } \\
& N & Mean & SD & Mean & SD & Mean & SD \\
\hline Experimental & & & & & & & \\
(Concept Map) & 61 & 20.87 & 8.85 & 82.87 & 12.09 & 62.00 & 3.24 \\
Control (CTM) & 56 & 20.48 & 10.23 & 30.45 & 10.97 & 10.00 & 0.74 \\
\hline
\end{tabular}

The data presented in Table 1 shows that the experimental group had a mean score of 20.87 in the pretest and a mean score of 82.87 in the post-test making a pre-test, posttest mean gain of experimental group is 62.00. The control group had a mean score of 20.48 in the pre-test and a mean score of 30.45 in the posttest making a pretest, posttest mean gains of control group to be 10.00 . With this result, the students in the experimental group performed better in the achievement test than the students in the control group. Hence, concept mapping instructional strategy improved students' achievement in technical drawing.

Research Question 2: What is the effect of concept mapping on students' interest in technical drawing?

Table 2: Mean and Standard Deviation of mean interest scores of Students' taught Technical Drawing using Concept Mapping instructional Strategy and Conventional Teaching Method

\begin{tabular}{|lccccccc|}
\hline Group & \multicolumn{3}{c}{ Pre-test } & \multicolumn{2}{c}{ Post-test } & \multicolumn{2}{c|}{ Gains } \\
& N & Mean & SD & Mean & SD & Mean & SD \\
\hline Experimental (Concept Map) & 61 & 45.20 & 7.75 & 61.54 & 7.28 & 16.34 & 0.47 \\
Control (CTM) & 56 & 37.25 & 6.91 & 42.07 & 7.28 & 4.82 & 0.37 \\
\hline
\end{tabular}

The data presented in Table 2 shows that the experimental group had a pretest interest mean of 45.20 with a standard deviation of 7.75 and a posttest mean score of 61.54 and standard deviation of 7.28 making a pre-test, posttest mean and standard deviation gains of experimental group to be 16.34 and 0.47 respectively. The control group had a pretest interest mean of 37.25 and a standard deviation of 6.91 with a posttest mean score of 42.07 and standard deviation of 7.28 making a pretest, posttest interest mean and standard deviation gains of control group to be 4.82. This result implies that concept mapping instructional technique improved students' interest in technical drawing.

Hypothesis 1: There is no significant difference in the achievement mean scores of technical students' taught technical drawing with Concept mapping and conventional teaching method. 
Table 3: ANCOVA of the mean achievement scores of students in taught technical drawing using Concept Mapping instructional Strategy and conventional teaching method

\begin{tabular}{|lllcrc|}
\hline Source & $\begin{array}{l}\text { Sum of } \\
\text { Squares }\end{array}$ & Df & $\begin{array}{l}\text { Mean } \\
\text { Square }\end{array}$ & F & Sig. \\
\hline Corrected Model & $13611.058^{\mathrm{a}}$ & 2 & 6805.529 & 218.226 & .000 \\
Intercept & 2290.294 & 1 & 2290.294 & 73.441 & .000 \\
Pretest Achi & 2543.697 & 1 & 2543.697 & 81.566 & .000 \\
Methods & 4657.612 & 1 & 4657.612 & 149.351 & .000 \\
Error & 3555.164 & 114 & 31.186 & & \\
Total & 336244.000 & 117 & & & \\
Corrected Total & 17166.22 & 116 & & & \\
\hline
\end{tabular}

The result in Table 3 shows that an F-ratio of 149.351 with associated probability value of 0.00 was obtained with regards to the mean achievement score of students taught technical drawing using concept mapping instructional technique and conventional teaching method. Since the associated probability $(0.00)$ is less than 0.05 set at level of significance, therefore, the null hypothesis which states that there is no significant difference in the performance of technical students' taught technical drawing using concept mapping and conventional teaching method is rejected. Consequently, there is a significant difference in the performance of technical students' taught technical drawing using concept mapping and conventional teaching method.

Hypothesis 2: There is no significant difference in the Mean interest score of technical students taught technical drawing using Concept mapping and conventional teaching method.

Table 4: ANCOVA of the mean interest scores of technical students taught Technology using Concept Mapping and those taught using Conventional teaching Method

\begin{tabular}{|lccccc|}
\hline Source & $\begin{array}{c}\text { Sum of } \\
\text { Squares }\end{array}$ & Df & $\begin{array}{c}\text { Mean } \\
\text { Square }\end{array}$ & F & Sig. \\
\hline Corrected Model & $80274.342^{\mathrm{a}}$ & 2 & 40137.171 & 322.276 & .000 \\
Intercept & 60330.058 & 1 & 60330.058 & 484.412 & .000 \\
Pretest Int & 38.910 & 1 & 38.910 & .312 & .577 \\
Methods & 80133.841 & 1 & 80133.841 & 643.263 & .000 \\
Error & 14197.880 & 114 & 124.543 & & \\
Total & 485050.000 & 117 & & & \\
Corrected Total & 94472.222 & 116 & & & \\
\hline
\end{tabular}

The result in Table 4 shows that an F-value of 643.263 with associated probability value of 0.00 was obtained with regards to the mean interest score of students taught technical drawing using concept mapping instructional technique and conventional teaching method. Since the associated probability (0.00) is less than 0.05 set at level of significance, therefore, the null hypothesis which states that there is no significant difference in the mean interest scores of technical students' taught technical drawing using concept mapping and conventional teaching method is rejected. Consequently, there is a significant difference in the mean interest scores of technical students' taught technical drawing using concept mapping and conventional teaching method, with higher mean interest gain in favour of those in the experimental group taught using concept mapping.

\section{Discussion of Findings}

The study revealed that there was significant difference in the performance of students due to instructional methods. The students taught with concept mapping obtained a higher mean achievement score than the students taught with the conventional teaching method. The high mean score by the experimental group indicated that the objective of the instructional strategy was realized and a good mastery of the concepts was achieved and this enabled the students in the experimental group to perform better. The teacher in the experimental group used concept maps to bring to bay the desired prerequisite information, skills or behaviour to the knowledge of the students. This is line with Onyeshi (2014) who asserted that if teaching style employed closely matches the student preferred style of acquiring knowledge, learning will be easier, more natural, and achievement will improve. Similarly, the tendency of better performance by the experimental group taught using concept mapping might be that the technique provides a visual image of concepts under study that enabled the students to focus easily and readily revise learnt task anytime when necessary (Novak \& Canas, 2008). The finding could also be due to the ability of the technique to create deeper understanding of the concepts under study realized through group and individual construction of the concept maps thereby leading to the realization of meaningful learning through integration of the learnt concepts. The strategy made learning an active process where the students were led to construct their own understanding of a given concept thereby taking cognizance of individual differences in terms of learning rate. This finding is in line with that of similar experimental studies by Imoko (2005); Ezekannagha (2007) \& Eneasato (2010) respectively, where the experimental 
treatment (concept mapping) was more effective than the control treatment (conventional teaching method). These authors reported that the effectiveness of concept mapping has been demonstrated with difficult concept and has been established to be a powerful strategy in achievement. This could be as a result that concept mapping is a graphic representation of concepts taught that aided active participation and led to better achievement. The low performance of the students in conventional teaching method group conforms to previous study of Oviawe, Ezeji \& Uwameiye (2015), who reported poor performance in the control group (conventional teaching method). However, the finding of this study is at variance with that of Imhanlanhimi \& Aluede (1997) who reported that students in the experimental group were outscored by students in a traditional expository group on every concept in a standard test.

The effect of concept mapping instructional strategy on students' interest in technical drawing as shown in Table 2 reveals that the students in the experimental group who were taught technical drawing using concept mapping were more interested in technical drawing. The students in the experimental group obtained a higher mean interest score than their counterparts in the control group. The findings of this study implies that concept mapping instructional strategy had a positive impact on the students in that it spurred the students' interest in technical drawing. The effect of concept map was positively realized in the experimental group compared to those in control group who had a low mean interest score. This could be attributed to the use of concept map strategy that aroused and sustained the interest of students in the experimental group more than those in the control group. The finding of this study corroborates the assertion of Okigbo \& Okeke (2011) that students are likely to be more engaged in the learning activities that appeal to their interest. It is pertinent to state that the use of concept maps arouses the interest of students in learning technical drawing which led to improving their achievement in the subject. Keter, Barchok \& Ng'ene (2014) posited that concept mapping approach of teaching and learning enhanced the teaching and learning of secondary school students in biology to support the finding of this study.

In response to hypothesis 1 , the findings in Table 3 revealed that a significant change in the mean achievement scores was found to exist among the technical drawing students' taught with concept mapping strategy and conventional teaching method with those in the experimental group taught with concept mapping having higher mean gain.

In response to hypothesis 2 , the findings in Table 4 revealed that a significant change in interest was found to exist among the students in the experimental group taught technical drawing with concept mapping strategy than among those taught using the conventional teaching method. This finding is in line with the findings of Imoko \& Agwagah (2006) that students' interest can be improved through the use of appropriate teaching technique.

\section{Conclusion and Recommendations}

The result of this study revealed that concept mapping strategy is more effective and spurred students interest in technical drawing. It is hoped that concept mapping instructional strategy is harnessed in teaching technical drawing and other technical and vocational subjects in Nigeria technical colleges. Based on the findings of this study, the following recommendations were made:

1. Technical drawing teachers should be encouraged to incorporate concept mapping strategy in their teaching and learning process to help develop students' interest in technical drawing.

2. Nigerian Government should her Ministry of Education and other relevant bodies in charge of curriculum development should develop a comprehensive guide on concept mapping strategy in technical drawing curriculum.

3. Government should organize training and retraining on the use of concept mapping strategy for technical teachers in technical colleges.

\section{References}

[1]. Okorie, J.U. (2001). Introduction to vocational education. Unpublished manuscripts. Department of vocational teacher education, University of Nigeria, Nsukka

[2]. Okoro, O.M. (1993). Principles and methods in vocational and technical education. Nsukka: University Trust Publishers.

[3]. Oviawe, J.I. (2016). Benefits and Limitations of E-learning for Technical Drawing in Edo State Model Secondary Schools. International Journal of Academic Research in Progressive Education and Development 5 (3), 52-64.

[4]. National Board for Technical Education (2012). Examiners report on academic achievement in vocational and technical education. Benin: National Business and Technical Education Board

[5]. Aduda, D. (2003). Meeting gives tips on how to improve science. Nairobi, Kenya: Nation Media Group

[6]. Oviawe, J.I., Ezeji, S.C.O.A., \& Uwameiye, R. (2015). Comparative effectiveness of three methods on the academic performance of students in building technology in Nigerian polytechnics. European Scientific Journal 11 (12), 274-285. www.eujournal.org/index.php/esj/article/view/5481

[7]. Abkpa, B.O. \& Iji, C.O. (2011). Effect of Mastery learning approach on senior secondary school students' achievement in Geometry. Journal of Science Teachers Association of Nigeria. 45(1), 207-223.

[8]. Olunloye, O. (2010). Mass failure in Mathematics: A National disaster. Tribune of 07/02/2010 retrieved from http://www.tribune.com.nig on 05/08/2016 
[9]. Ford, N. \& Chen, S. (2007).matching/mismatching revisited: An empirical study of learning and teaching styles. British Journal of Educational Technology, 32(1), 5-22.

[10]. Keter, K.J., Barchok, H.K. \& Ng'ene, J.K. (2014). Effects of cooperative mastery learning approach on students' motivation to learn chemistry by gender. Journal of Education and Practice, 5(8), 91-97.

[11]. Imoko, I.B. \& Agwagah, U.N.C. (2006). Improving students' interest in Mathematics through the concept mapping technique: A focus on gender. Journal of Research in Curriculum and Teaching 1(1), 30-38.

[12]. Obioma, G.O. (2005). Emerging issues in Mathematics education in Nigeria with emphasis on the strategies for effective teaching and learning of word problems and algebraic expressions. Journal of issues on Mathematics, 8(1), 1-8.

[13]. Okereke, S.C. (2006). Effects of Prior knowledge of implications of Mathematical tasks/concepts to Career types and gender on students' achievement, interest and retention. The $47^{\text {th }}$ STAN Annual Conference Proceeding. 253-259.

[14]. Iyekekpolor, A.S.O. (2007). Cooperate strategies for combating poor performance in Mathematics. Makurdi: Onauvi Publishers Ltd.

[15]. Anyagh, P.I. \& Ok'wu, E.I. (2010). Effect of formula teaching approach on students' achievement in Algebra. Journal of Research in Curriculum and Teaching. 5(1), 374-379.

[16]. Federal Ministry of Education (2001). The National Master Plan for Technical and Vocational Development in nigeria in the 21 century with the blue print for the Decade 2010. Abuja: Federal Ministry of Education

[17]. Eneasato, C.J. (2010). Effects of concept mapping on students' achievement and retention in geography. Ph.D thesis, University of Nigeria, Nsukka.

[18]. Cakir, M. (2008). Constructivist approach to learning in science and their implication for science pedagogy: A literature review. Retrieved on 08/04/16 from http://www.ijese.com/IJESE_v3n4_Cakir.pdf

[19]. Walker, G.H. (2002). Concept mapping and curriculum development. Retrieved 13/07/16 from http://www.utc.edu/Aministration/WalkerTeachingResourceCenter/FacultyDevelopment/ConceptMapping/

[20]. Novak, J.D. (2008). Concept Maps: What the heck is this? Retrieved 03/05/2012 from: https://www.msu.edu/-luckie/ctools/

[21]. Coffey, J.W. \& Canas, A.J. (2003). A summary of literature pertaining to the use of concept maps. Retrieved 08/02/14 from http://www.csudh.edu/../advorg03.htm

[22]. Elorriaga, J.A. (2006). Applications of a Concept Mapping Tool. Retrieved from http://cmc.ihmc.us/cmc2006Papers/cmc2006.pdf

[23]. Novak, J.D. \& Canas, A.J. (2008). The theory underlying concept maps and how to construct and use them. Retrieved 03/05/2016 from http://cmap.ihmc.us

[24]. Ali, A. (2006). Conducting research in education and the social sciences. Enugu: Tashiwa Networks Ltd.

[25]. National Board for Technical Education (2003). Building technology - national diploma curriculum and course specifications . Kaduna

[26]. Onyeshi, C.N. Effects of strategic content learning strategy on students' mathematics task persistence, self-efficacy and achievement. Unpublished Masters Thesis of the Department of Educational Foundations, University of Nigeria, Nsukka. 2014

[27]. Imoko, B.I. Effect of concept mapping on students' achievement and interest in trigonometry. Unpublished Ph.D thesis, University of Nigeria, Nsukka. 2005

[28]. Ezekannagha, G.N. Effects of concept mapping and cognitive styles on achievement of students in integrated science. Ph.D thesis, University of Nigeria, Nsukka. 2007.

[29]. Imhanlahimi, E., \& Aluede, O. (1997). The effectiveness of discovery and expository methods of teaching biology: a case study of Adolo college, Benin City. Journal of Science Teaching and Learning 3 (1\&2), 1-7.

[30]. Okigbo, E.C. \& Okeke, S.O.C. (2011). Effects of games and analogies on students' interest in Mathematics. The 53 ${ }^{\text {rd }}$ STAN Annual Conference Proceedings, 127-142. 